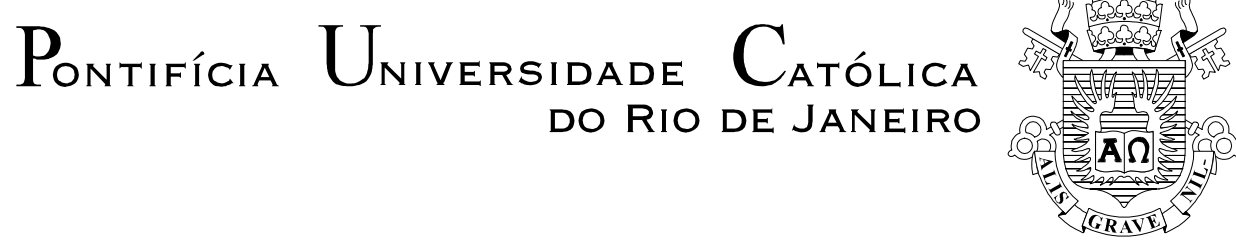

Licinio Nascimento de Almeida Junior

\title{
Conjecturas para uma \\ Retórica do Design [Gráfico]
}

Tese de Doutorado

Tese apresentada ao Programa de Pós-Graduação em Design do Departamento de Artes \& Design da PUC-Rio como parte dos requisitos parciais para obtenção do título de Doutor em Design.

Orientadora:

Prof. ${ }^{a}$ Vera Lúcia Moreira dos Santos Nojima

Volume I

Rio de Janeiro

Fevereiro de 2009 


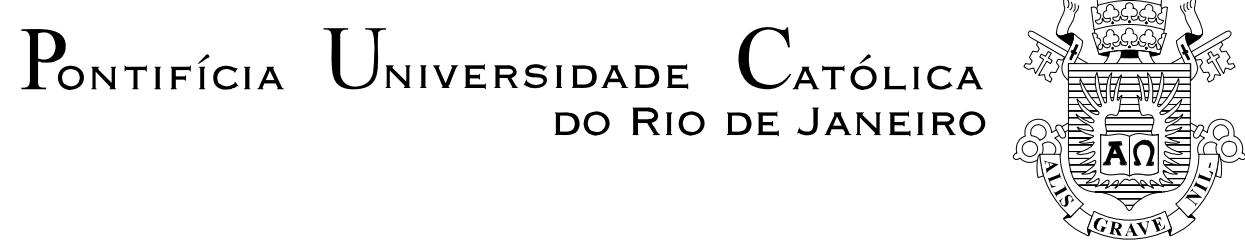

Licinio Nascimento de Almeida Junior

\section{Conjecturas para uma Retórica do Design [Gráfico]}

Tese apresentada ao Programa de Pós-Graduação em Design da PUC-Rio como requisito parcial para obtenção do título de Doutor em Design. Aprovada pela Comissão Examinadora abaixo assinada.

Prof. ${ }^{a}$ Vera Lúcia Moreira dos Santos Nojima

Orientadora

Departamento de Artes \& Design - PUC-Rio

Prof. ${ }^{a}$ Mônica Cristina de Moura

Anhembi-Morumbi

Prof. Marcos da Costa Braga

USP

Prof. ${ }^{a}$ Helena Franco Martins

Departamento de Letras - PUC-Rio

Prof. ${ }^{a}$ Lucy Carlinda da Rocha Niemeyer

Departamento de Artes \& Design - PUC-Rio

Prof. Paulo Fernando Carneiro de Andrade Coordenador Setorial do Centro de Teologia e Ciências Humanas - PUC-Rio

Rio de Janeiro, 16 de fevereiro de 2009 
Todos os direitos reservados. É proibida a reprodução total ou parcial do trabalho sem autorização da universidade, do autor e do orientador.

\section{Licinio Nascimento de Almeida Junior}

Graduou-se em Comunicação Social (habilitação em Publicidade e Propaganda) pela Universidade Gama Filho em 1995. Especializou-se em Marketing pela Escola Superior de Propaganda e Marketing em 1998. Especializou-se em Interface, Internet e Multimídia pela Universidade Federal Fluminense em 2000. Obteve o grau de Mestre em Design pela PUC-Rio em 2003. Em 2005, publicou, no II Encontro Internacional de Ciências do Design (Unidcom/IADE), realizado em Lisboa, o artigo The globalization in the Brazilian media. Em 2006, publicou, no $7^{\circ} \mathrm{P} \& \mathrm{D}$ Design, o artigo Contextualizar o Design?, que levanta questões epistemológicas sobre o campo do Design. Também publicou o resumo Representações metonímicas do Design: uma questão de identidade no II Simpósio Nacional Discurso, Identidade e Sociedade. Em 2007, publicou artigos diretamente voltados ao estudo da Retórica e do Design, intitulados: Ferramental para uma Retórica do Design Gráfico, no $4^{\circ}$ Congresso Internacional de Pesquisa em Design (Anped), e A Retórica do Design Gráfico: reflexões para uma Teoria do Design, no III Congresso Internacional de Semiótica (ABES). Publicou ainda, na Revista Alceu (n.14), o artigo Globalização e desterritorialização: reflexões preliminares sobre uma ideologia, que discorre sobre influências ideológicas da Propaganda em um cenário globalizado. Atualmente trabalha como Profissional de Comunicação Social da Transportadora Brasileira Gasoduto Bolívia-Brasil S.A.

Ficha Catalográfica

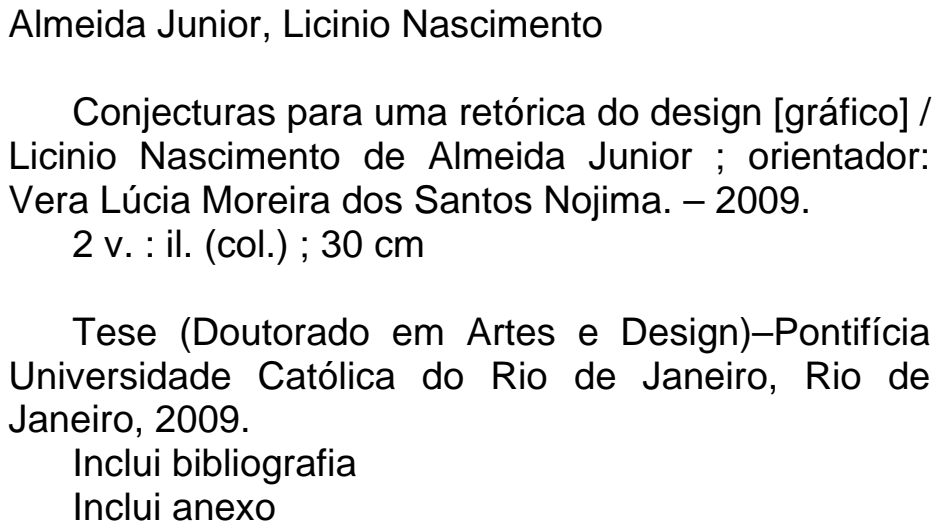

1. Artes - Teses. 2. Design. 3. Design Gráfico. 4. Retórica. 5. Semiótica. 6. Epistemologia. 7. Teoria do Design. 8. Imagem midiática. 9. Ideologia. I. Nojima, Vera Lúcia Moreira dos Santos. II. Pontifícia Universidade Católica do Rio de Janeiro. Departamento de Artes e Design. III. Título. 


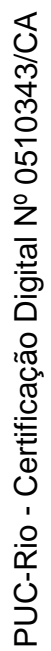

Aos designers, retores do nosso cotidiano, por uma Teoria do Design. 


\section{Agradecimentos}

À professora, orientadora e amiga Vera Nojima, pela dedicação, parceria, ensinamentos e conselhos indispensáveis durante todo meu percurso para a concepção e execução desta Tese.

À Coordenação de Aperfeiçoamento de Pessoal de Nível Superior (CAPES), pelo importante auxílio concedido para a elaboração deste trabalho.

Às professoras Helena Martins e Lucy Niemeyer, pelas valiosas sugestões e considerações para o aprimoramento da Pesquisa durante o processo de qualificação.

Ao professor Luiz Antônio Coelho, por ter me oferecido a oportunidade de desenvolver e apresentar um seminário sobre a obra de Jacques Durand, trabalho inspirador para a realização da Pesquisa.

Ao jornalista Sergio Costa, da Insight Engenharia de Comunicação, pela determinante ajuda ao disponibilizar os contatos das Editoras Abril, Globo e Três.

À designer Louise Novais, companheira inseparável. Que os debates sobre Design, seu carinhoso incentivo e sua fundamental ajuda para a execução de minha Pesquisa sejam apenas o início de nossa história...

Aos meus pais, Licinio Nascimento de Almeida e Nilza Benedita Xavier de Almeida, por serem, além de conselheiros e inestimáveis amigos, meus exemplos de vida e fiéis incentivadores em todos os momentos.

A todos os amigos da PUC-Rio, em especial a Luciana Claro, Welida Barbosa, Guilherme Xavier e Gabriel “Gabiru” Batista, por compartilharem aflições e torcerem pelo meu êxito.

Ao amigo e professor Homero dos Santos, pelas preciosas lições sobre Língua Portuguesa, pelo incansável estímulo voltado à minha vida de "concurseiro" e pelo garimpado presente que trouxe a obra de Jacques Durand.

Aos grandes amigos, desde a época de Colégio Batista Shepard, geólogo e petroleiro Samuel Magalhães Viana e engenheiro Leonardo da Silva Araújo, pelo apoio e pela partilha de experiências acadêmicas vivenciadas.

Ao amigo Marcos Antonio Batista de Carvalho, pela apurada revisão que contribuiu para o aperfeiçoamento textual da Tese. 
Aos funcionários do Departamento de Artes e Design e da Divisão de Bibliotecas e Documentação da PUC-Rio, pela colaboração oferecida durante todo o curso de pós-graduação.

Aos professores que participaram da Banca Examinadora, pelas importantes contribuições para a Pesquisa.

A todos aqueles que apostaram em mim e me ajudaram para a conclusão desta Tese. 


\section{Resumo}

Almeida Junior, Licinio Nascimento; Nojima, Vera Lúcia Moreira dos Santos (orientadora). Conjecturas para uma Retórica do Design [Gráfico]. Rio de Janeiro, 2009. 2 v. Tese de Doutorado - Departamento de Artes e Design, Pontifícia Universidade Católica do Rio de Janeiro.

O Design evidencia-se como uma atividade projetual de elementos voltados à reprodução. As modalidades produtivas dessa atividade são consolidadas, sobretudo, pela manipulação de imagens. A concretização perceptível e decifrável dessas imagens pressupõe a efetivação de uma semiose que, ao possibilitar significações, cria enunciações. Ao visar a adesão de um público/auditório, essas enunciações entrelaçam-se em um sistema retórico que, fundamentado nos cânones da Retórica Aristotélica, centra-se num etos, num patos e num logos, como formas de argumentações persuasivas. Revela-se, então, uma intrigante, ou pelo menos sedutora, relação entre a Retórica e a Imagem. Ao confrontar a ideia dessa relação com os atributos engendrados pelos produtos do Design, vislumbra-se a manifestação de uma Retórica do Design. Baseando-se no Tratado da argumentação, de Chaïm Perelman, em que à Retórica é credenciada sua renovação, esta Tese faz uma abordagem reflexiva sobre a contribuição da Retórica para uma Teoria do Design. Como a atuação do Design abarca um vasto campo exploratório, selecionou-se uma modalidade específica para o estudo, o Design Gráfico. Pressupôs-se a existência de uma Retórica inerente à natureza do Design Gráfico. Foram tomados, como caso exemplar, projetos gráficos de capas das principais revistas noticiosas brasileiras. Como resultado, chegou-se a um conjunto de pressupostos teóricos balizadores para uma Retórica do Design Gráfico e ao reconhecimento da pertinência da imbricação entre Design Gráfico e Retórica na construção e delineamento de uma Teoria do Design. Por fim, foi cogitada a possibilidade de evidenciar propósitos ideológicos em projetos gráficos, por meio de análise retórica.

\section{Palavras-chave}

Design Gráfico, Retórica, Semiótica, Epistemologia, Teoria do Design, Imagem Midiática, Ideologia. 


\section{Abstract}

Almeida Junior, Licinio Nascimento; Nojima, Vera Lúcia Moreira dos Santos (advisor). Conjectures for Rhetoric [Graphic] Design. Rio de Janeiro, 2009. 2 v. Doctoral Thesis - Departamento de Artes e Design, Pontifícia Universidade Católica do Rio de Janeiro.

Design is expressed as an activity involving the projection of elements related to reproduction. Productive types of this activity are consolidated, especially, by the manipulation of images. The concrete and decipherable perception of these images presupposes the use of semiotics to enable meaning and create pronouncements. To hold a public or an audience, these pronouncements are interwoven within a system of rhetoric based on the inclusion of Aristotelian Rhetoric and based on an ethos, a pathos and a logos, as forms of persuasive arguments. It is then manifested as a stimulating or at least seductive relationship between Rhetoric and Image. When comparing the idea of this relationship with the attributes engendered by the products of Design, an expression of a Design Rhetoric can be seen. Based on Chaïm Perelman's Treatise on argumentation in which Rhetoric is the foundation of its renovation, this Theory creates a reflective approach regarding the contribution of Rhetoric toward a Theory of Design. Since the purpose of Design encompasses a vast exploratory field, a specific type has been selected for the study - Graphic Design. It presupposes the existence of Rhetoric inherent to the nature of Graphic Design. As a sample case, covers of the Brazilian leading news magazines have been taken. As a result, a set of delimiting theoretical presuppositions were arrived at for a Graphic Design Rhetoric and for the recognition of the relevance of the imbrications of Graphic Design and Rhetoric in the construction and delineation of a Design Theory. Finally, the possibility of providing evidence of ideological proposals in graphic projects based on rhetorical analysis was also included.

\section{Keywords}

Graphic Design, Rhetoric, Semiotics, Epistemology, Design Theory, Media Image, Ideology. 


\section{Resumen}

Almeida Junior, Licinio Nascimento; Nojima, Vera Lúcia Moreira dos Santos (directora). Conjeturas para una Retórica del Diseño [Gráfico]. Rio de Janeiro, 2009. 2 v. Tesis de Doctorado - Departamento de Artes e Design, Pontifícia Universidade Católica do Rio de Janeiro.

El Diseño se evidencia como una actividad que proyecta elementos orientados a la reproducción. Las modalidades productivas de esa actividad se consolidan, sobre todo, por la manipulación de imágenes. La concreción perceptible y descifrable de esas imágenes presupone la realización de una semiosis que, al posibilitar significaciones, crea enunciaciones. Al buscar la adhesión de un público/auditorio, esas enunciaciones se entrelazan en un sistema retórico que, basado incluso en los cánones de la Retórica Aristotélica, se centra en un etos, en un patos y en un logos, como formas de argumentación persuasiva. Se revela, entonces, una intrigante, o al menos seductora, relación entre la Retórica y la Imagen. Al confrontar la idea de esa relación con los atributos engendrados por los productos del Diseño, se vislumbra la manifestación de una Retórica del Diseño. Basándose en el Tratado de la argumentación de Chaïm Perelman, en el que a la Retórica se le acredita su renovación, esta Tesis realiza un abordaje reflexivo sobre la contribución de la Retórica a una Teoría del Diseño. Como la actuación del Diseño abarca un vasto campo exploratorio, se seleccionó una modalidad específica para el estudio, el Diseño Gráfico. Se presupuso la existencia de una Retórica inherente a la naturaleza del Diseño Gráfico. Se tomaron, como caso ejemplar, proyectos gráficos de portadas de las principales revistas de noticias brasileñas. Como resultado, se llegó a un conjunto de presupuestos teóricos demarcadores de una Retórica del Diseño Gráfico, y al reconocimiento de la pertinencia de la imbricación entre Diseño Gráfico y Retórica en la construcción y delineación de una Teoría del Diseño. Por último, se trató la posibilidad de evidenciar propósitos ideológicos en proyectos gráficos, por medio del análisis retórico.

\section{Palabras clave}

Diseño Gráfico, Retórica, Semiótica, Epistemología, Teoría del Diseño, Imagen Mediática, Ideología. 


\section{Résumé}

Almeida Junior, Licinio Nascimento; Nojima, Vera Lúcia Moreira dos Santos (directeur de thèse). Conjectures pour une Rhétorique du Design [Graphique]. Rio de Janeiro, 2009. 2 v. Thèse de Doctorat Departamento de Artes e Design, Pontifícia Universidade Católica do Rio de Janeiro.

Le Design est connu en tant qu'activité projectuelle d'éléments consacrés à la reproduction. Les modalités productives de cette activité sont consolidées, notamment par la manipulation d'images. La concrétisation perceptible et déchiffrable de ces images présuppose la mise en place d'une sémiose qui, du fait de privilégier des significations, crée des énonciations. Lorsqu'elles envisagent l'adhésion d'un public/assistance, ces énonciations s'entrecroisent dans un système rhétorique qui, basé y compris dans les canons de la Rhétorique Aristotélique, est centré sur un ethos, un pathos et un logos, en tant que formes d'argumentations persuasives. Il en ressort alors, une intrigante, ou tout au moins séductrice relation entre la Rhétorique et l'Image. Une fois confrontée l'idée de cette relation avec les attributs engendrés par les produits du Design, on envisage la manifestation d'une Rhétorique du Design. Tout en tenant comme base le Traité de l'argumentation de Chaïm Perelman, selon lequel à la Rhétorique est autorisé son renouvellement, cette Thèse présente une approche réflexive sur la contribution de la Rhétorique pour une Théorie du Design. Du fait que l'étendue du Design comprend un vaste champ exploratoire, une modalité spécifique a été sélectionnée pour l'étude: le Design Graphique. On a présupposé l'existence d'une Rhétorique inhérente à la nature du Design Graphique. En tant que cas exemplaire, des projets graphiques de couvertures des principaux magazines de nouvelles brésiliennes ont été considérés. À guise de résultat, nous sommes arrivés à un ensemble de présupposés théoriques conduisant à une Rhétorique du Design Graphique et à la reconnaissance de la pertinence de l'imbrication entre Design Graphique et Rhétorique dans la construction et le délinéament d'une Théorie du Design. Finalement, la possibilité de mettre en évidence des propos idéologiques dans des projets graphiques a été cogitée, au moyen d'analyse rhétorique.

\section{Mots clefs}

Design Graphique, Rhétorique, Sémiotique, Epistémologie, Théorie du Design, Image Médiatique, Idéologie. 


\section{Sumário}

\section{VOLUME I}

1. À guisa de exórdio 26

2. Da Retórica ao Design 30

3. Design, Imagem e Retórica 43

3.1. Design e Epistemologia 45

3.2. Para o delineamento de uma Teoria do Design 47

3.3. Amplitude de uma especificidade para a Teoria do Design 49

3.4. Noções de Retórica 52

3.5. Alfabetismo visual 59

3.6. Noções de Imagem 61

3.7. Funções da Imagem 65

4. Sobre a Retórica Aristotélica 69

4.1. Invenção 72

4.1.1. Gêneros do discurso 73

4.1.2. Dimensões persuasivas do discurso 75

4.2. Disposição 82

4.3. Elocução 86

4.4. Ação 92

5. Século XX, a Nova Retórica de Perelman 93

5.1. Os âmbitos da argumentação 98

5.1.1. Demonstração, argumentação e adesão 98

$\begin{array}{ll}\text { 5.1.2. Os auditórios } & 101\end{array}$

5.1.3. Convencimento e persuasão 104 
5.2. Pontos de partida da argumentação 105

5.2.1. Acordo sobre o real 106

5.2.2. Acordo sobre o preferível 108

5.3. Dados do discurso, escolha, presença e comunhão 111

5.4. Técnicas argumentativas 116

5.4.1. Argumentos quase-lógicos 117

5.4.2. Argumentos baseados na estrutura do real 126

5.4.3. Argumentos que fundamentam a estrutura do real 130

5.4.4. Argumentos por dissociação 134

6. Uma leitura sobre a Retórica da Imagem 137

6.1. A teoria barthesiana sobre a Retórica da Imagem 137

6.2. Contextualizando a teoria barthesiana 142

6.3. Retórica e imagem publicitária, por Jacques Durand 148

6.4. A validade da classificação das figuras 153

$\begin{array}{ll}\text { 7. Revisitando as Figuras de Retórica } & 156\end{array}$

8. Semiótica, Ideologia e Retórica 163

8.1. Fundamentos da teoria triádica do signo 164

8.2. Uma confluência entre as teorias de Peirce e de Perelman 171

$\begin{array}{ll}\text { 8.3. Sobre Ideologia e Retórica } & 173\end{array}$

9. Informação e persuasão no âmbito da Retórica do Design [Gráfico] 181

10. O ano de 2006 em revista 186

10.1. Lula nas capas das revistas noticiosas 188

10.2. Análise das capas das revistas noticiosas 194

10.3. Apreciações sobre matérias de capa 267

10.3.1. Análise de conteúdo classificatória 269

10.3.2. Análise de conteúdo por associação de palavras $\quad 274$ 


\section{VOLUME II}

11. O cimento que faz a liga 276

12. Conjecturas para uma Retórica do Design Gráfico - pressupostos balizadores

13. Epílogo

294

14. Referências bibliográficas

303

15. Referências eletrônicas

16. Referências de entrevistas, banco de imagens, fonograma e semanários

17. Referências das figuras

320

18. Referências dos quadros

323

19. Apêndices 325

19.1. Apêndice I - Entrevistas 325

19.1.1. Revista Veja 325

19.1.2. Revista Época 327

19.1.3. Revista IstoÉ 329

19.1.4. Detalhamento da análise de conteúdo por associação de palavras 330

19.1.5. Documentação das entrevistas 332

19.2. Apêndice II - Uma viagem panorâmica sobre a Retórica 340

19.2.1. A Retórica e sua origem forense 340

19.2.2. Górgias e o início da Retórica Literária 342

19.2.3. A Retórica Sofística 343

19.2.4. A Retórica Platônica 345

19.2.5. Isócrates e a moralização da Retórica 348 
19.2.6. Cícero e Quintiliano: início do período latino

19.2.7. A Retórica no sistema educacional 353

19.2.8. A Retórica e o Cristianismo 356

19.2.9. Declínio e retomada da Retórica 358

19.3. Apêndice III - Projeções para futuras pesquisas 365

19.3.1. Gradações da retoricidade 365

19.3.2. Design, Retórica e especificidades 366

19.3.3. O lugar da Metáfora no Design? 367

20. Anexos 381

20.1. Anexo I - Capas das revistas noticiosas 381

20.2. Anexo II - Textos primários da Poética e da Retórica de Aristóteles 415

20.3. Anexo III - As Artes Liberais 417

20.4. Anexo IV - Santo Agostinho 423 


\section{Lista de figuras}

Figura 1 - Marcas de bebidas derivadas do suco de laranja. 143

Figura 2 - Capa da revista Veja, edição 1975... 146

Figura 3 - Campanha da Benetton "Food for Life", 2003.

Figura 4 - Relação triádica proposta por Peirce. 166

Figura 5 - Época 404, 13/02/2006. 188

Figura 6 - Época 412, 10/04/2006. 188

Figura 7 - Época 413, 17/04/2006. 189

Figura 8 - Época 433, 04/09/2006. 189

Figura 9 - Época 436, 25/09/2006. 189

Figura 10 - Época 439, 16/10/2006. 189

Figura 11 - Época 442, 06/11/2006. 189

Figura 12 - Veja 1937, 28/12/2005. 190

Figura 13 - Veja 1952, 19/04/2006. 190

Figura 14 - Veja 1955, 10/05/2006. 190

Figura 15 - Veja 1970, 23/08/2006. 190

Figura 16 - Veja 1975, 27/09/2006. 190

Figura 17 - Veja 1979, 25/10/2006. 190

Figura 18 - Veja 1980, 1\%/11/2006. 191

Figura 19 - Veja 1981, 08/11/2006. 191

Figura 20 - Veja 1989, 30/12/2006. 191

Figura 21 - IstoÉ 1892, 25/01/2006. 191

Figura 22 - IstoÉ 1922, 23/08/2006. 191

Figura 23 - IstoÉ 1924, 06/09/2006. 192

Figura 24 - IstoÉ 1928, 04/10/2006. 192

Figura 25 - IstoÉ 1930, 18/10/2006. 192

Figura 26 - IstoÉ 1932, 1\%/11/2006. 192

Figura 27 - IstoÉ 1933, 08/11/2006. 192

Figura 28 - IstoÉ 1938, 13/12/2006. 192

Figura 29 - IstoÉ 1940, 27/12/2006. 193

Figura 30 - Exemplos de elementos periféricos. 195 
Figura 31 - Posicionamentos das assinaturas marcárias das revistas. 196

Figura 32 - Legendas das malhas gráficas. 196

Figura 33 - Veja, edição 1970 e IstoÉ, edição 1922.

Figura 34 - Destaque às imagens tipográficas da matéria de capa. 199

Figura 35 - A representação do político-candidato... 200

Figura 36 - A marca "PB" é responsável pelo exórdio do discurso... 200

Figura 37 - A estratégia retórica do Design Gráfico direciona... 203

Figura 38 - A fotomontagem ocupa quase a totalidade... 205

Figura 39 - Na composição, Lula ocupa o centro do cenário. 206

Figura 40 - Imagens tipográficas da chamada e dos subtítulos... 208

Figura 41 - Malhas gráficas totalmente desconstruídas... 209

Figura 42 - IstoÉ, edição 1924 e Época, edição 433.

Figura 43 - Malhas gráficas da capa de IstoÉ 1924... 212

Figura 44 - A imagem dourada de Lula ocupa a maior parte... 213

Figura 45 - O olhar de Lula é direcionado ao auditório... 214

Figura 46 - "A EXPLOSÃO DO LULISMO": a ênfase gráfica... 215

Figura 47 - Imagens tipográficas da matéria de capa de Época. 216

Figura 48 - A imagem fotográfica de Lula ocupa o maior espaço... $\quad 217$

Figura 49 - O gesto de Lula direciona a leitura da chamada. 219

Figura 50 - O design gráfico de ambas as capas aplica... 220

Figura 51 - Veja, edição 1975 e Época, edição 436.

Figura 52 - Praticamente não há a concorrência de outros... 223

Figura 53 - O fundo da capa passa as noções de serenidade... 225

Figura 54 - O Brasão da República está posicionado próximo... 228

Figura 55 - O peso da imagem de Lula está na parte superior... 229

Figura 56 - Os matizes da textura do fundo contribuem com o efeito... 230

Figura 57 - A imagem tipográfica da matéria de capa de Época... 231

Figura 58 - A imagem de Lula sem a combinação da imagem... 232

Figura 59 - Malhas gráficas de Época: o olhar de Lula... 233

Figura 60 - No design gráfico da matéria de capa adotado por Veja... 234

Figura 61 - Veja, edição 1980 e IstoÉ, edição 1932.236

Figura 62 - A tipografia da matéria principal vem grafada... 238

Figura 63 - Os perfis dos rostos dos candidatos são compostos... $\quad 239$ 
Figura 64 - Os perfis ocupam proporções iguais na composição...

Figura 65 - A imagem icônico-indicial de céu ao fundo do cenário... 242

Figura 66 - As imagens fotográficas dos presidenciáveis... 244

Figura 67 - Os lábios dos candidatos estão cerrados... 245

Figura 68 - Os matizes das cores, invertidos, fazem a mensagem... $\quad 247$

Figura 69 - A ação cromática atua retoricamente, ampliando... 247

Figura 70 - Imagens tipográficas da matéria de capa. 248

Figura 71 - Desconstrução total das composições gráficas... 250

Figura 72 - Época, edição 442; IstoÉ, edição 1933 e Veja... 251

Figura 73 - A imagem de Lula ocupa o maior espaço da composição. 253

Figura 74 - Lula expressa um olhar pensativo, voltando-se para cima. 253

Figura 75 - A verbalização isolada da imagem tipográfica... 254

Figura 76 - As imagens tipográficas são divididas em três partes... 256

Figura 77 - A chamada em caixa-alta e corpo maior utiliza o efeito... 257

Figura 78 - Lula "lê" que seu próximo passo será o momento... 258

Figura 79 - O fundo apresenta a assinatura, em tipografia... 259

Figura 80 - A fotomontagem de Lula está sangrada... 260

Figura 81 - O olhar de Lula é fixo para o auditório de Veja. 261

Figura 82 - A secção diagonal do leiaute e a disposição... 262

Figura 83 - Nas imagens tipográficas, destaca-se o uso das... 263

Figura 84 - Onde está grafado "pífio", a imagem de Lula... 264

Figura 85 - Manchas gráficas totalmente desconstruídas... 266

Figura 86 - Placas de trânsito. 287

Figura 87 - Placas de trânsito: animais na Austrália e no Zimbábue. 287

Figura 88 - Cuidado, animais alados! 289

Figura 89 - Solicitação usada para cessão de entrevista... 332

Figura 90 - Carta de apresentação do pesquisador... 333

Figura 91 - Documento comprobatório de vínculo... 334

Figura 92 - Anexo do correio eletrônico, em formato PDF... 335

Figura 93 - Resposta de Eurípedes Alcântara, da Revista Veja... 336

Figura 94 - Continuação da resposta de Eurípedes Alcântara. 337

Figura 95 - Resposta de Marcos Marques, da Revista Época... 338

Figura 96 - Resposta de Mário Simas Filho, da Revista IstoÉ... 339 
Figura 97 - Mapa do mundo helenístico... 352

Figura 98 - Controles remotos. 375

Figura 99 - Época 397, 26/12/2005*. 381

Figura 100 - Época 398, 02/01/2006. 381

Figura 101 - Época 399, 09/01/2006. 381

Figura 102 - Época 400, 16/01/2006. 382

Figura 103 - Época 401, 23/01/2006. 382

Figura 104 - Época 402, 30/01/2006. 382

Figura 105 - Época 402 (Anúncio)*. 382

Figura 106 - Época 403, 06/02/2006. 382

Figura 107 - Época 404, 13/02/2006. 382

Figura 108 - Época 405, 20/02/2006. 383

Figura 109 - Época 406, 27/02/2006. 383

Figura 110 - Época 407, 06/03/2006. 383

Figura 111 - Época 408, 13/03/2006. 383

Figura 112 - Época 409, 20/03/2006. 383

Figura 113 - Época 410, 27/03/2006. 383

Figura 114 - Época 411, 03/04/2006. 384

Figura 115 - Época 412, 10/04/2006. 384

Figura 116 - Época 413, 17/04/2006. 384

Figura 117 - Época 414, 24/04/2006. 384

Figura 118 - Época 415, 1\%05/2006. 384

Figura 119 - Época 416, 08/05/2006. 384

Figura 120 - Época 417, 15/05/2006. 385

Figura 121 - Época 418, 22/05/2006. 385

Figura 122 - Época 419, 29/05/2006. 385

Figura 123 - Época 420, 05/06/2006. 385

Figura 124 - Época 420 (Encarte)*. 385

Figura 125 - Época 421, 12/06/2006. 386

Figura 126 - Época 422, 19/06/2006. 386

Figura 127 - Época 423, 26/06/2006. 386

Figura 128 - Época 424, 03/07/2006. 386

Figura 129 - Época 425, 10/07/2006. 386 
Figura 130 - Época 426, 17/07/2006.

Figura 131 - Época 427, 24/07/2006.

Figura 132 - Época 428, 31/07/2006.

Figura 133 - Época 429, 07/08/2006.

Figura 134 - Época 430, 14/08/2006. 387

Figura 135 - Época 431, 21/08/2006. 388

Figura 136 - Época 432, 28/08/2006. 388

Figura 137 - Época 433, 04/09/2006. 388

Figura 138 - Época 434, 11/09/2006. 388

Figura 139 - Época 435, 18/09/2006. 388

Figura 140 - Época 436, 25/09/2006. 388

Figura 141 - Época 437, 02/10/2006. 389

Figura 142 - Época 438, 09/10/2006. 389

Figura 143 - Época 439, 16/10/2006. 389

Figura 144 - Época 440, 23/10/2006. 389

Figura 145 - Época 441, 30/10/2006. 389

Figura 146 - Época 442, 06/11/2006. 390

Figura 147 - Época 443, 13/11/2006. 390

Figura 148 - Época 444, 20/11/2006. 390

Figura 149 - Época 445, 27/11/2006. 390

Figura 150 - Época 446, 04/12/2006. 390

Figura 151 - Época 447, 11/12/2006. 390

Figura 152 - Época 448, 18/12/2006. 391

Figura 153 - Época 449, 25/12/2006. 391

Figura 154 - Época 450, 1\%01/2007*. 391

Figura 155 - Veja 1937, 28/12/2005*. 392

Figura 156 - Veja 1938, 11/01/2006. 392

Figura 157 - Veja 1939, 18/01/2006. 392

Figura 158 - Veja 1940, 25/01/2006. 392

Figura 159 - Veja 1941, 1\%02/2006. 393

Figura 160 - Veja 1942, 08/02/2006. 393

Figura 161 - Veja 1943, 15/02/2006. 393

Figura 162 - Veja 1944, 22/02/2006. 393 
Figura 163 - Veja 1945, 1\%03/2006. 393

Figura 164 - Veja 1946, 08/03/2006. 393

Figura 165 - Veja 1947, 15/03/2006. 394

Figura 166 - Veja 1948, 22/03/2006. 394

Figura 167 - Veja 1949, 29/03/2006. 394

Figura 168 - Veja 1950, 05/04/2006. 394

Figura 169 - Veja 1951, 12/04/2006. 394

Figura 170 - Veja 1952, 19/04/2006. 395

Figura 171 - Veja 1953, 26/04/2006. 395

Figura 172 - Veja 1954, 03/05/2006. 395

Figura 173 - Veja 1955, 10/05/2006. 395

Figura 174 - Veja 1956, 17/05/2006. 395

Figura 175 - Veja 1957, 24/05/2006*. 395

Figura 176 - Veja 1957, 24/05/2006*. 396

Figura 177 - Veja 1958, 31/05/2006. 396

Figura 178 - Veja 1959, 07/06/2006. 396

Figura 179 - Veja 1960, 14/06/2006. 396

Figura 180 - Veja 1961, 21/06/2006. 396

Figura 181 - Veja 1962, 28/06/2006. 396

Figura 182 - Veja 1963, 05/07/2006. 397

Figura 183 - Veja 1964, 12/07/2006. 397

Figura 184 - Veja 1965, 19/07/2006. 397

Figura 185 - Veja 1966, 26/07/2006. 397

Figura 186 - Veja 1967, 02/08/2006. 397

Figura 187 - Veja 1968, 09/08/2006. 397

Figura 188 - Veja 1969, 16/08/2006. 398

Figura 189 - Veja 1970, 23/08/2006. 398

Figura 190 - Veja 1971, 30/08/2006. 398

Figura 191 - Veja 1972, 06/09/2006. 398

Figura 192 - Veja 1973, 13/09/2006. 398

Figura 193 - Veja 1974, 20/09/2006. 399

Figura 194 - Veja 1975, 27/09/2006. 399

Figura 195 - Veja 1976, 14/10/2006. 399 
Figura 196 - Veja 1977, 11/10/2006.

399

Figura 197 - Veja 1978, 18/10/2006.

399

Figura 198 - Veja 1979, 25/10/2006.

399

Figura 199 - Veja 1980, 1\%/11/2006.

400

Figura 200 - Veja 1981, 08/11/2006.

400

Figura 201 - Veja 1982, 15/11/2006.

400

Figura 202 - Veja 1983, 22/11/2006.

400

Figura 203 - Veja 1984, 29/11/2006.

400

Figura 204 - Veja 1985, 06/12/2006.

401

Figura 205 - Veja 1986, 13/12/2006.

401

Figura 206 - Veja 1987, 20/12/2006.

401

Figura 207 - Veja 1988, 27/12/2006.

401

Figura 208 - Veja 1989, 30/12/2006. 401

Figura 209 - Veja 1990, 10/01/2007*. 402

Figura 210 - IstoÉ 1889, 28/12/2005*.

402

Figura 211 - IstoÉ 1890, 11/01/2006.

403

Figura 212 - IstoÉ 1890 (Time)*.

403

Figura 213 - IstoÉ 1891, 18/01/2006.

403

Figura 214 - IstoÉ 1892, 25/01/2006.

403

Figura 215 - IstoÉ 1893, 1\%02/2006.

403

Figura 216 - IstoÉ 1894, 08/02/2006.

403

Figura 217 - IstoÉ 1895, 15/02/2006.

404

Figura 218 - IstoÉ 1896, 22/02/2006.

404

Figura 219 - IstoÉ 1897, 1\%03/2006.

404

Figura 220 - IstoÉ 1898, 08/03/2006.

404

Figura 221 - IstoÉ 1899, 15/03/2006.

404

Figura 222 - IstoÉ 1900, 22/03/2006. 404

Figura 223 - IstoÉ 1901, 29/03/2006. 405

Figura 224 - IstoÉ 1902, 05/04/2006. 405

Figura 225 - IstoÉ 1903, 12/04/2006. 405

Figura 226 - IstoÉ 1904, 19/04/2006. 405

Figura 227 - IstoÉ 1905, 26/04/2006. 405

Figura 228 - IstoÉ 1905 (Encarte)*. 406 
Figura 229 - IstoÉ Especial / abril*. 406

Figura 230 - IstoÉ 1906, 03/05/2006. 406

Figura 231 - IstoÉ 1906 (Encarte)*. 406

Figura 232 - IstoÉ 1907, 10/05/2006. 406

Figura 233 - IstoÉ 1907 (Encarte)*. 406

Figura 234 - IstoÉ 1908, 17/05/2006. 407

Figura 235 - IstoÉ 1908 (Encarte)*. 407

Figura 236 - IstoÉ 1909, 24/05/2006. 407

Figura 237 - IstoÉ 1909 (Encarte) * . 407

Figura 238 - IstoÉ 1910, 31/05/2006. 407

Figura 239 - IstoÉ 1910 (Encarte)*. 407

Figura 240 - IstoÉ 1911, 07/06/2006. 408

Figura 241 - IstoÉ 1912, 14/06/2006. 408

Figura 242 - IstoÉ 1913, 21/06/2006. 408

Figura 243 - IstoÉ 1914, 28/06/2006. 408

Figura 244 - IstoÉ 1915, 05/07/2006. 408

Figura 245 - IstoÉ 1916, 12/07/2006. 408

Figura 246 - IstoÉ 1917, 19/07/2006. 409

Figura 247 - IstoÉ 1918, 26/07/2006. 409

Figura 248 - IstoÉ 1919, 02/08/2006. 409

Figura 249 - IstoÉ 1920, 09/08/2006. 409

Figura 250 - IstoÉ 1921, 16/08/2006. 409

Figura 251 - IstoÉ 1922, 23/08/2006. 409

Figura 252 - IstoÉ 1923, 30/08/2006. 410

Figura 253 - IstoÉ 1924, 06/09/2006. 410

Figura 254 - IstoÉ 1925, 13/09/2006. 410

Figura 255 - IstoÉ 1926, 20/09/2006. 410

Figura 256 - IstoÉ 1927, 27/09/2006. 410

Figura 257 - IstoÉ 1928, 04/10/2006. 411

Figura 258 - IstoÉ 1929, 11/10/2006. 411

Figura 259 - IstoÉ 1930, 18/10/2006. 411

Figura 260 - IstoÉ 1931, 25/10/2006. 411

Figura 261 - IstoÉ 1932, 1\%/11/2006. 411 
Figura 262 - IstoÉ 1933, 08/11/2006. 411

Figura 263 - IstoÉ 1934, 15/11/2006. 412

Figura 264 - IstoÉ 1935, 22/11/2006. 412

Figura 265 - IstoÉ 1936, 29/11/2006. 412

Figura 266 - IstoÉ 1937, 06/12/2006. 412

Figura 267 - IstoÉ 1938, 13/12/2006. 412

Figura 268 - IstoÉ 1939, 20/12/2006. 413

Figura 269 - IstoÉ 1940, 27/12/2006. 413

Figura 270 - IstoÉ Especial / dezembro*. 413

Figura 271 - IstoÉ 1941, 10/01/2007*. 413

Figura 272 - Primeiras páginas da Poética de Aristóteles... $\quad 415$

Figura 273 - Primeiras páginas da Retórica de Aristóteles... 416

Figura 274 - Alegoria das Sete Artes Liberais [1590s]. 417

Figura 275 - Um jovem sendo introduzido às Sete Artes Liberais... $\quad 418$

Figura 276 - As Artes Liberais na fachada da catedral de Chartres. 419

Figura 277 - As Sete Artes Liberais no Hortus Deliciarum [1180] 420

Figura 278 - Santo Agostinho ensinando Retórica e Filosofia... 423 


\section{Lista de quadros}

Quadro 1 - Esquema das dimensões da comunicação... 66

Quadro 2 - Esquema das funções da linguagem... 66

Quadro 3 - Algumas definições das funções da linguagem. 67

Quadro 4 - Algumas definições das funções da linguagem... 68

Quadro 5 - Proposta esquemática para a Arte Retórica Aristotélica. $\quad 71$

Quadro 6 - As operações da técnica retórica em Aristóteles. 72

Quadro 7 - Os três gêneros do discurso.

Quadro 8 - A metáfora aristotélica por analogia. 90

Quadro 9 - Relações fundamentais das figuras. 151

Quadro 10 - Operações fundamentais das figuras. 151

Quadro 11 - Quadro geral de classificação das figuras de retórica. 152

Quadro 12 - Figuras de Escolha na Nova Retórica. 157

Quadro 13 - Figuras de Escolha na Nova Retórica (continuação). 158

Quadro 14 - Figuras de Presença na Nova Retórica. 159

Quadro 15 - Figuras de Presença na Nova Retórica (continuação). 160

Quadro 16 - Figuras de Comunhão na Nova Retórica. 161

Quadro 17 - Categorias dos Signos propostas por Peirce. 170

Quadro 18 - Linha do tempo das matérias de capa sobre Lula... 194

Quadro 19 - The traditional phases of rhetorical production... 290

Quadro 20 - Resultado da análise de conteúdo... 330

Quadro 21 - Continuação do resultado da análise de conteúdo... $\quad 331$ 
Em que pesem as variações internas do sistema, a retórica, lembremos, reinou no Ocidente durante dois milênios e meio, de Górgias a Napoleão III; tudo o que ela, imutável, impassível e quase imortal, viu nascer, crescer, desaparecer, sem comover-se nem se alterar: a democracia ateniense, as realezas egípcias, a República Romana, o Império Romano, as grandes invasões, o feudalismo, a Renascença, a monarquia, a Revolução; assimilou regimes, religiões, civilizações; agonizante desde o Renascimento, levou três séculos para morrer; e ainda não havia certeza de sua morte. A retórica dá acesso ao que chamaríamos de uma supercivilização: a do Ocidente, histórica e geográfica: foi a única prática (com a gramática, nascida depois dela) através da qual nossa sociedade reconheceu a linguagem, sua soberania (...), que era também, socialmente, uma “senhorialidade” (...). 